\title{
Indigenous technology of tapping, collecting and processing of coconut (Cocos Nucifera) sap and its quality in Blitar Regency, East Java, Indonesia
}

\author{
${ }^{1}$ Somawiharja, Y., ${ }^{1 *}$ Wonohadidjojo, D.M, ${ }^{2}$ Kartikawati, M., ${ }^{2}$ Suniati, F.R.T. and \\ ${ }^{2}$ Purnomo, $\mathrm{H}$. \\ ${ }^{1}$ Department of Informatics. Ciputra University, Indonesia \\ ${ }^{2}$ Department of Food Technology, Ciputra University, Surabaya, Indonesia
}

\begin{abstract}
Article history:
Received: 11 March 2018

Received in revised form: 14 April 2018

Accepted: 20 April 2018

Available Online: 9 May 2018
\end{abstract}

\section{Keywords:}

Sugar component,

Fresh coconut sap,

Coconut sugar

DOI:

https://doi.org/10.26656/fr.2017.2(4).075

\begin{abstract}
Coconut sugar is widely used in Indonesian and other Asian countries cuisine for centuries and also very popular as a natural sweetener in Indonesia, and nowadays it is also becoming popular as a sweetener in some developed countries. This product is still produced in cottage level with a wide quality level and this study tried to investigate the indigenous technology of tapping, collecting and processing coconut sap in Kemloko Village, Blitar Regency and the sugar components of either fresh coconut sap without and with preservative as a raw material in producing coconut sugar. The HPLC analysis of sugar components of samples showed that the fresh coconut sap without preservative start undergoes fermentation as its sucrose content decreasing while its fructose and glucose contents were increased compared to the one with preservative. On the contrary, the sucrose component of coconut sugar prepared using fresh coconut sap without preservative were lower while its fructose and glucose contents were higher compared to the one prepared using fresh coconut sap with preservative. It can be concluded that the indigenous technique of tapping, collecting and processing fresh coconut sap in this area affected the quality of coconut sugar. Therefore, an investigation of better and safer tapping, collecting and processing techniques are crucial needed to improve the coconut sugar quality.
\end{abstract}

\section{Introduction}

Coconut sugar as one of sweetener which has a lower glycemic index (GI) compared to cane sugar becoming popular nowadays in developed countries as reported by Solanki (2016). Trinindad et al. (2010) observed that coconut sap sugar has a GI in the range of $35 \pm 4$ and $42 \pm 4$. Furthermore, Solanki (2016) also noted that the demand for palm sugar in European countries within the last five years is very high.

Fresh sap from palm trees including coconut (Cocos nucifera) tree is the raw material in producing palm or coconut sugars. In Indonesia, this sap is known as nira and in other countries coconut fresh sap has its own name such as toddy (Sri Lanka), maprau (Thailand), tori (India), lagbi (North Africa) and lubki (Egypt). This fresh sap is collected from cutting the inflorescence of palm trees and contained sucrose, glucose and fructose as well as other nutrients such as minerals, vitamins, antioxidants and phytochemicals (Nathanael, 1970; Purnomo, 1992; Purnomo and Mufida, 2004; Purnomo,
2007; Hebbar et al., 2015).

According to Kusumah (1992), Purnomo (1992) and Purnomo and Surjoseputro (2001), in Indonesia coconut fresh sap are collected by climbing about 15-17 $\mathrm{m}$ height of coconut tree to cut the inflorescence. The collecting container is tied up on the spadix inflorescence after cutting it and left about 9-12 hours. If preservative is not added to the collecting container, the collected fresh sap could easily have fermented after 15 hours. While Purnomo and Surjoseputro (2001) and Hebbar et al. (2015) noted that the most common natural preservative used are limestone powder or solution, jack fruit (Artocarpus heterophylus) wood chip, mangosteen (Garciana mangosteen) exocarp fruit skin, and finely cut Hall bark (Artha acuminata) chips or combination of these preservatives and sodium metabisulphite is also quite popular as chemical preservative in preventing the fermentation process of fresh sap.

Coconut sugar is prepared by boiling the already strained fresh sap in a casting iron wok at $105^{\circ} \mathrm{C}$ for 
about 3 hours or until the syrup reaches about $65^{\circ}$ Brix and ready for moulding in a half coconut shell. (Purnomo and Surjoseputro, 2001; Purnomo and Mufida, 2004). Purnomo (1992), Purnomo and Suryoseputro (2001), Ho et al. (2008), and Srikaeo and Thongta (2015) reported that palm sugar included coconut sugar had been used for centuries as traditional sweeteners in a wide range of Asian cuisine. However, these sugars are produced traditionally at cottage industries level, hence there is a wide range of coconut sugar quality. Hori et al. (2000) also observed technology of coconut sugar production in East Java and Bali and showed that there were different methods in each place. Even there was some research done by some researcher published litte information on sugar components of fresh coconut sap and its coconut sugar and technology of coconut sugar production in Kemloko Village, Blitar Regency, East Java. Therefore in this study, an attempt was made to investigate the indigenous technology of tapping, collecting and processing coconut sap in Kemloko Village, Blitar Regency and to determine the sugar components of fresh coconut sap without and with preservative and its coconut sugars.

\section{Materials and method}

\subsection{Materials}

Secondary data were collected from the Department of Agriculture and Food and the Department of Trade of Blitar Regency, while the primary data were collected by observation, interview of the village leader and coconut sugar producer in the Kemloko Village as study location, and measurements of certain parameters.

Fresh sap and coconut sugar were collected from the coconut plantation and coconut sugar processor in Kemloko village, Blitar Regency, East Java. The fresh samples were taken at random after afternoon tapping where one container without preservative and the other one was added limestone powder (approximately $10 \mathrm{~g} / \mathrm{L}$ fresh sap) as a preservative. The collection time started from spatches the inflorescence until bringing down the collected fresh sap was about 12 hours before further processing to produce coconut sugar. As soon as the collected fresh sap was brought down approximately 100 $\mathrm{ml}$ were filled in a sterilized bottle transported in a coolbox to the laboratory and before analysis, the samples were stored in refrigerator at about $4^{\circ} \mathrm{C}$.

While coconut sugar was prepared by cleaning the fresh sap using plastic strainer before pouring in the casting iron wok and boiled at $90-100^{\circ} \mathrm{C}$ for about 3-4 hours. These sap syrup $\left(88^{\circ} \mathrm{Brix}\right)$ were then molded in a half coconut shell and the already cold molded coconut sugar were taken randomly and stored in PVC pouches in refrigerator at about $4^{\circ} \mathrm{C}$ before laboratory analysis.

\subsection{Method}

Snowball sampling was used by asking village leader to select the coconut farmer to be interviewed, observation and determination of coconut sap collection, processing and coconut sugar production. The quality variables measured were total soluble solid using hand refractometer RHB-90ATC/China (58-90\%), and total plate count (TPC) using nutrient agar by SNI method 012897-1992 point 81 (SNI, 1992b).

Sugar components of these samples were analysed in The Indonesian Sugar Research Institute Laboratory in Pasuruan Regency, East Java. The sample preparation for HPLC analysis was carried out as follow: one gram sample was measured, dissolved in $100 \mathrm{ml}$ aquadest, filtered, and injected to HPLC using SNI method 012892-1992 (SNI, 1992a). The HPLC analysis of sugar components of fresh coconut sap without and with preservative and its coconut sugar were performed using a set of HPLC Knauer, flow rate $0.6 \mathrm{ml} /$ minute, column Aminex HPX-87C, temperature $65^{\circ} \mathrm{C}$, mobile phase $\mathrm{H}_{2} \mathrm{O}$ (aquabides), detector RI 2300, pressure $40 \mathrm{Mpa}$.

\section{Results and discussion}

According to the Indonesian Statistics Center in Blitar Regency the rainy season usually comes around November until July and in 2014 it reached above 35 $\mathrm{mm}$. The increase of rainfall amount will influence the agricultural product (BPS, 2015). Most of the small and medium industries in Blitar Regency are coconut sugar industries. In 2013, there were more than 68 centers of coconut sugar industries which cover 9094 business units that are located in Sanankulon, Srengat, Ponggok and Nglegok Districts (BAPPEDA, 2013; BPS, 2017). The average of coconut sugar production is about 11,035 tonnes/year (BAPPEDA, 2013) and therefore, Blitar Regency is considered as a suitable place for the development of nira production.

The survey results showed that according to an officer of the Department of Agriculture and Food, in one day each coconut sap tapper should climb between 10 to 25 trees for tapping and collecting the coconut sap using a used paint can as a container. Twice a day the coconut farmer should climb the tree for cutting the inflorescence and bring down the yesterday collected coconut sap for further processing (Figure 1). Each tree could produce 1 to 3 inflorescences and it could be tapped around one month with a production of 2-2.5 L coconut sap each inflorescence each day.

The observation and interview results in selected 
village namely Kemloko, Nglegok District, Blitar Regency showed that there were more than 35 farmers of coconut sugars. The coconut trees in this village are about 7 to $15 \mathrm{~m}$ height and therefore due to the hard job from year to year the number of coconut sap tappers decreasing especially the youngster, who prefer to work in sand mining or other jobs with higher income and lower risk. Another challenge which affected to stay in tapper profession is climate changes which affected the quality of coconut sap and resulted in a low grade of coconut sugar. Besides the risk of fallen down during climbing especially during the rainy season, the risks are quite high as the tree trunk becomes slippery. The tappers also have a side job mainly in agriculture field and very limited extension activities are given to these farmers from officers in charge such as extension service officer of Department of Agriculture and Food, Blitar Regency. A coconut sap tappers community association is also already established; however, this group is rarely used for improving the coconut sugar production although it has been used for development of other agriculture issues.

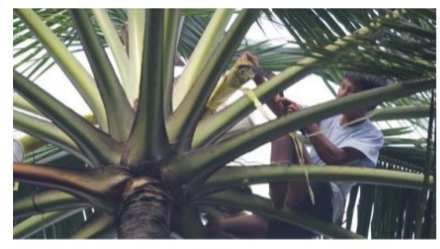

(A)

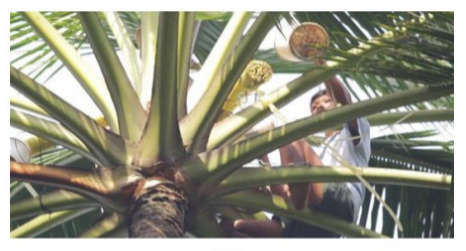

(B)
Figure 1. The coconut farmer was cutting the inflorescence (A) and put on the collecting can (B)

Ta'lin (2013) also noted that traditional way of tapping the inflorescence is very risky as it needs to climb the tree for slicing and bringing down the previously collected coconut sap. The high risk of falling off the tree during tapping and collecting the coconut sap and climbing the coconut tree with more than $10 \mathrm{~m}$ height is a physically hard job. Therefore, an improved technology for safely tapping coconut sap is urgently needed.

The collected coconut sap in some collecting recycle paint cans are then poured through a plastic fine mesh strainer to filter the dirt and other contaminants such as insects, ants, pollen and remains of the flowers into a large shallow round bottom cast iron wok as shown in Figure 2.

The clean coconut sap in the cast iron wok was then boiled at $90-100^{\circ} \mathrm{C}$ for about 3-4 hours until reaching a soluble solid value of $88^{\circ}$ Brix and considered ready to be moulded in a half coconut shell. In this condition, coconut sap syrup is in the form of solid or semi-solid crystalline mass ready for consumption and known as coconut sugar or palm jaggery (Figure 3 ).

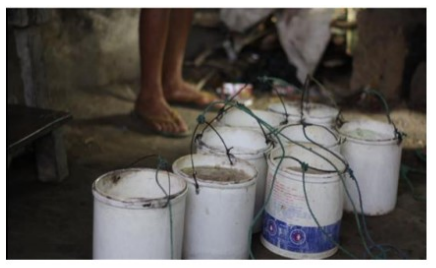

(A)

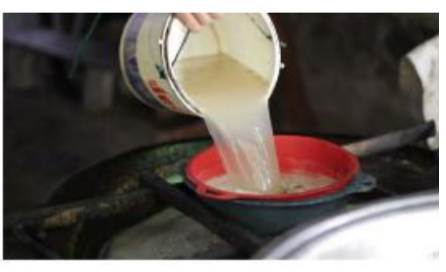

(B)
Figure 2. The recycle paint cans filled with coconut $\operatorname{sap}(\mathrm{A})$ and Filtering the coconut sap using a fine plastic mesh strainer (B)

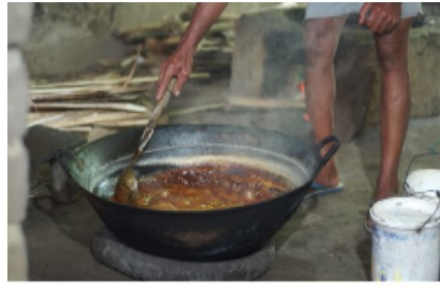

(A)

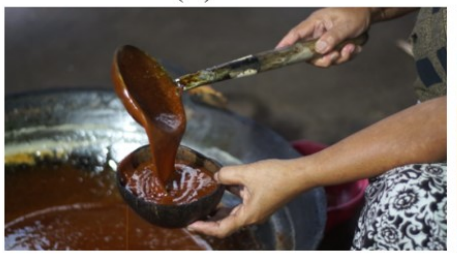

(C)

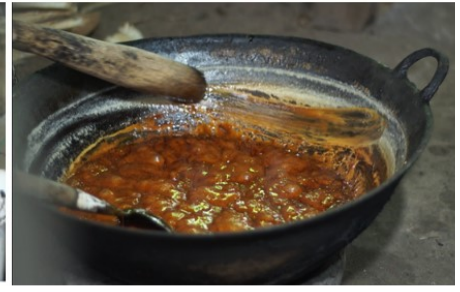

(B)

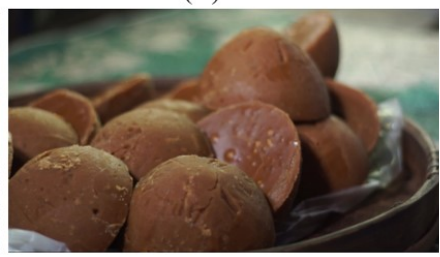

(D)
Figure 3. The boiled coconut sap syrup ready for forming coconut sugar (A, B and C) and coconut sugar ready for consumption (D)

Coconut sap without preservative and with limestone solution as a preservative as well as the coconut sugars from that sap was taken for laboratory analysis. The results showed that $\mathrm{pH}$ values of sap without and with preservative were 4.26 and 4.68 and the microbial count (TPC) were not countable/g and $1.2 \times 10^{2} \mathrm{CFU} / \mathrm{g}$, respectively. While the microbial count of coconut sugar without and with preservative was $1.2 \times 10^{2} \mathrm{CFU} / \mathrm{g}$ and $3.6 \times 10^{2} \mathrm{CFU} / \mathrm{g}$, respectively. According to Bondad (2017), in the Philippines national standard for coconut sap sugar (PNS/BAFPS 76, 2010), the microbial count (TPC number) is less than $10 \mathrm{CFU} / \mathrm{g}$. Phaichamnan et al. (2010) reported that microbial count in palm sugar concentrated was in the range of $1.20 \times 10^{3}-4.80 \times 10^{6}$ $\mathrm{CFU} / \mathrm{ml}$ samples and $\mathrm{pH}$ values in the range of 4.50 5.37. Kapillan et al. (2015) also observed a similar $\mathrm{pH}$ value of coconut sap without lime solution as preservative was 4.36 and bacterial count of $156 \times 10^{6}$ $\mathrm{CFU} / \mathrm{g}$ and if $1 \mathrm{~g} / \mathrm{l}$ lime concentration added to the coconut sap the bacterial count decreased to $12 \times 10^{6}$ $\mathrm{CFU} / \mathrm{g}$ with a $\mathrm{pH}$ value of 12.5 .

The sugar components of fresh coconut sap without and with preservative are presented in Table 1 and Figure 5 based on standard which is shown in Figure 4. It was observed that fresh sap without preservative had a 
Table 1. Sugar components of fresh coconut sap without and with preservative and its sugar

\begin{tabular}{lccc}
\hline Sample & $\begin{array}{c}\text { Sucrose } \\
(\%)\end{array}$ & $\begin{array}{c}\text { Fructose } \\
(\%)\end{array}$ & $\begin{array}{c}\text { Glucose } \\
(\%)\end{array}$ \\
\hline $\begin{array}{l}\text { Fresh coconut sap } \\
\text { without preservative }\end{array}$ & 1.76 & 5.76 & 4.46 \\
$\begin{array}{l}\text { Fresh coconut sap with } \\
\text { preservative }\end{array}$ & 5.76 & 3.23 & 2.25 \\
$\begin{array}{l}\text { Coconut sugar without } \\
\text { preservative }\end{array}$ & 49.41 & 14.15 & 15.60 \\
$\begin{array}{l}\text { Coconut sugar with } \\
\text { preservative }\end{array}$ & 57.05 & 5.45 & 6.97 \\
\hline
\end{tabular}
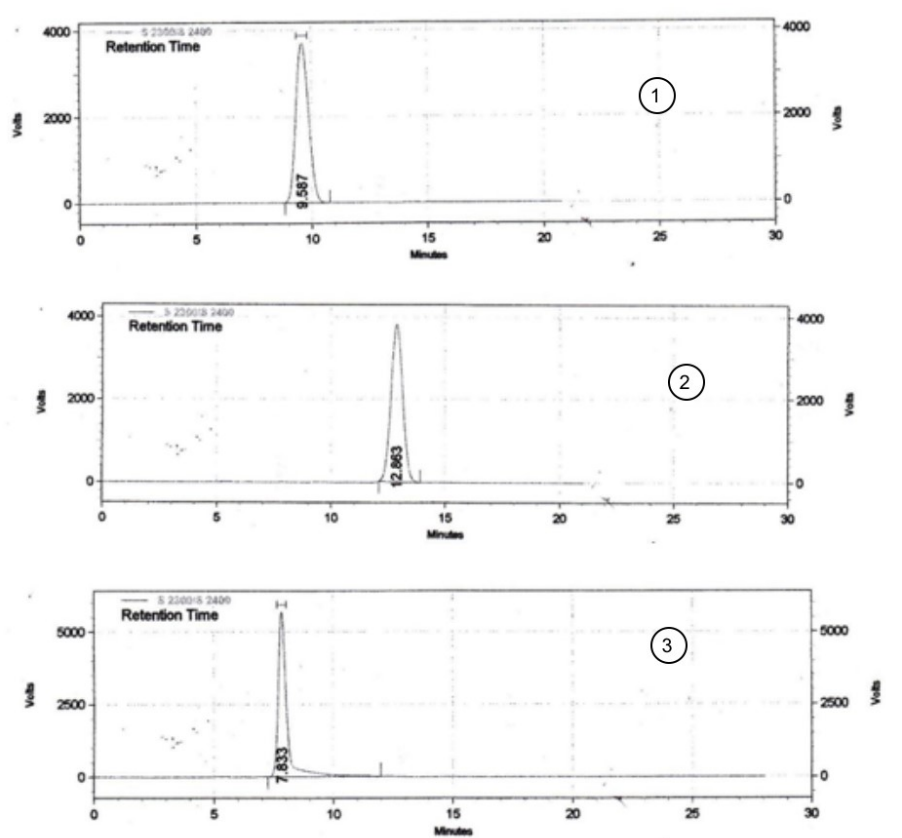

Figure 4. HPLC chromatograms of sucrose (1), fructose (2) and glucose (3) standard

lower content of sucrose $(1.76 \%)$ but higher fructose $(5.76 \%)$ and glucose $(4.46 \%)$ compared to the one with preservative which had a sucrose content of $5.76 \%$, fructose $3.23 \%$, and glucose $2.25 \%$. This condition showed that fresh coconut sap without preservative if collected for 12 hours undergoes fermentation, hence the sucrose was used by the fermentation microbes present in the sap and broke it into fructose and glucose. While in the fresh sap where preservative added the sucrose relatively high as fermentation process was retarded. According to Phaichamnan et al. (2010) reducing sugars (glucose and fructose) could be produced by microorganism in palm sap as a result of hydrolysis process of its sucrose content. It is interesting to note the study of Kalaiyarasi et al. (2013) where the microorganisms involved in fresh coconut sap fermentation were Candida glabrata, Kloeckera apiculata, Schizosaccharomyces pombe. The sucrose and glucose fermentation in Coconut sap were carried out by Schizosaccharomyces pombe and Pichia angophorae ferments sucrose at the later stages followed by Kloeckera apiculata and Candida glabrata play an important role in the fermentation of fructose and
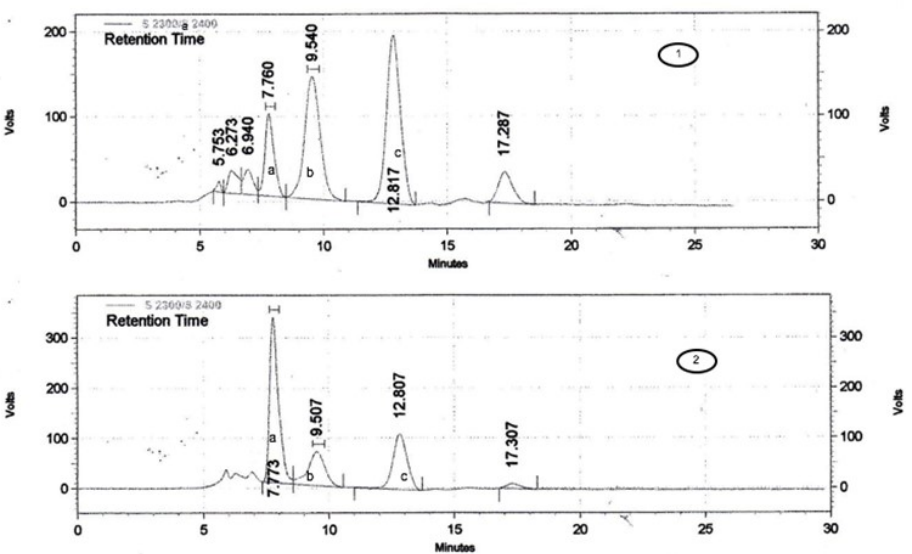

Figure 5. HPLC chromatograms of sugar components of fresh coconut sap without (1) and with preservative (2) (sucrose (a), glucose (b), fructose(c))

galactose.

Purnomo and Mufida (2004) reported that the afternoon tapping the inflorescence and collecting the fresh coconut sap next morning (about 12 hours) where 1 g sodium metabisulphite combined with $10 \mathrm{ml} 10^{\circ} \mathrm{Be}$ limestone solution for about $2 \mathrm{~L}$ fresh sap contained $18.72 \%$ sucrose. This high sucrose content due to the preservative added which retarded the fermentation process as it affected the growth of microorganisms. The nighttime temperature is usually lower than daytime which also slightly retarded the fermentation process as well. Furthermore, Ysidor et al. (2014) found that different coconut cultivar produced fresh sap with different sugar component as showed by the following result: Malayan Yellow Dwarf fresh sap contained sucrose of $12.24 \mathrm{~g} / 100 \mathrm{ml}$; Western Africa Tall contained sucrose of $9.40 \mathrm{~g} / 100 \mathrm{ml}$; improved hybrids PB 113( Cameroon Red Dwarf x improved Rennell Island Tall) contained sucrose of $10.38 \mathrm{~g} / 100 \mathrm{ml}$; and PB 121 (Malayan Yellow Dwarf x improved West African Tall) contained sucrose $10.31 \mathrm{~g} / 100 \mathrm{ml}$ respectively. While its glucose and fructose contents were $2.14 \mathrm{~g} / \mathrm{ml}$ to $3.73 \mathrm{~g} / 100 \mathrm{ml}, 1.63 \mathrm{~g} / 100 \mathrm{ml}$ to $1.84 \mathrm{~g} / 100 \mathrm{ml}$ and 1.24 $\mathrm{g} / 100 \mathrm{ml}$ to $1.52 \mathrm{~g} / 100 \mathrm{ml}$, respectively.

Hebbar et al. (2015) observed that fresh coconut sap after harvesting (8-12 hours from tapping to collecting) contained $15 \%$ sugar and decreased to about $6 \%$ while at the same time the reducing sugar level increased up to $5 \%$. While Misra (2016) reported that fresh coconut sap (neera) contained total sugars $14.4 \mathrm{~g} / \mathrm{ml}$ and total reducing sugars $9.85 \mathrm{~g} / 100 \mathrm{ml}$.

The sugar components of coconut sugars produced using fresh coconut sap without and with preservative are shown in Table 1 and Figure 6. Sucrose content of coconut sugar prepared using fresh coconut sap without preservative are lower (49.41\%) compared to sucrose content $(57.05 \%)$ of coconut sugar produced using fresh 
coconut sap with preservative. However, its glucose $(15.90 \%)$ and fructose $(14.15 \%)$ contents were higher compared to glucose $(6.97 \%)$ and fructose $(5.45 \%)$ of
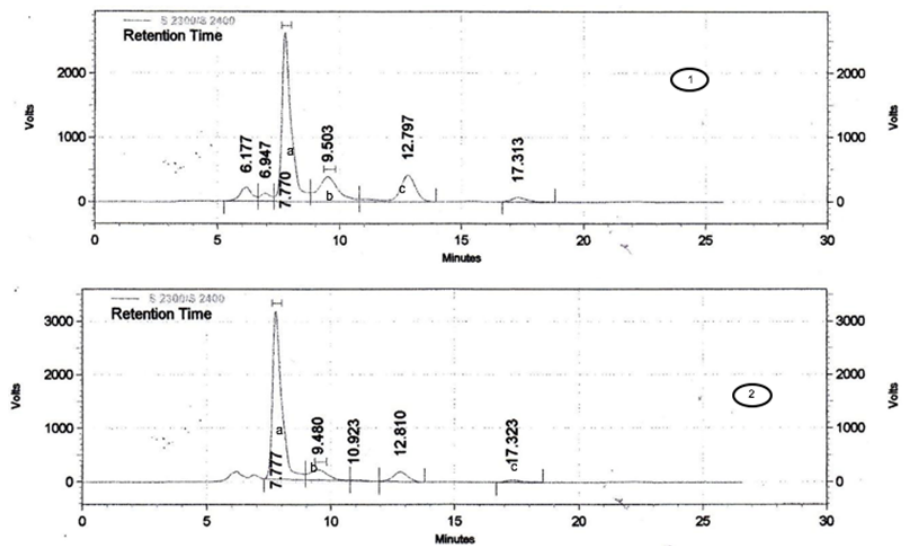

Figure 6. HPLC chromatograms of sugar components of coconut sugar produced using fresh coconut sap without (1) and with (2) preservative (sucrose (a), glucose (b), fructose(c))

coconut sugars prepared using fresh sap with preservative.

Total sugars of palm sugar samples varied from $23.77 \%$ to $71.89 \%$ and the reducing sugars were in the range of $3.54 \%$ to $23.94 \%$ and the wide variation of these sugars content may be possible due to the effect of microorganism contamination in samples. Sucrose content was converted to glucose and fructose by these microorganisms and finally produced organic acids or alcohols, besides these sugars are also as primary substances in caramelisation reaction during heating process especially at high temperature and long time. At the same time acceleration of hydrolysis reaction of sucrose may occur to produce reducing sugars which can interact with amino acids in Maillard reaction end up with dark brown color (Martins et al., 2001; Aider et al., 2007; Phaichamnan et al., 2010). The differences of either total sugars and reducing sugars content between studies are possibly caused by different coconut variety, techniques of tapping, collecting and processing of coconut sap, geographies, and climate. Hori et al. (2000) also reported that the different of sugar components are due to coconut variety, stage of coconut tree inflorescence maturity, climate condition as well as soil fertility. Therefore, a further study to investigate a better and safer tapping, collecting and processing techniques are essential in an effort to produce a high quality of coconut sugar.

\section{Conclusion}

The tapping, collecting and processing coconut sap in Kemloko village, Nglegok District, Blitar Regency are still carried out traditionally. This condition affected the quality and sugar component of end products. The coconut sugar produced by Kemloko Village containing relatively low sucrose, fructose and glucose content. Fresh coconut sap and coconut sugar without preservatives showed less sugar components than with preservatives, which is caused by microorganism. To improve a better quality of coconut sugar further study to investigate better and safer techniques in tapping, collecting and processing fresh coconut sap in this area is urgently needed.

\section{References}

Aider, M., Halleux, D.de. and Belkacemi, K. (2007). Production of granulated sugar from maple syrup with high content of inverted sugar. Journal of Engineering, 80(3), 791-797. https:// doi.org/10.1016/j.jfoodeng.2006.07.008

BAPPEDA. (2013). Blitar Regency (Kabupaten Blitar). Retrieved on May 15, 2017 from BAPPEDA Jawa Timur Website: http://bappeda.jatimprov.go.id/ bappeda/wp-content/uploads/potensi-kab-kota-2013/ kab-blitar-2013.pdf.

Bondad, A.A. (2017). Philippine National Standards for coconut sugar. Bureau of Agriculture and Fisheries Product Standards BPI Compound, Visayas Avenue, Diliman, Quezon City. Retrieved on June 22, 2017 from Website: http:/www.coconutboard.gov.in/ images/neera-Phil-stds-sap-sugar.pdf.

BPS. (2015). Statistics of Blitar Regency (Statistik Daerah Kabupaten Blitar). Retrieved on May 20, (2017) from Statistics of Blitar Regency Website: https://blitarkab.bps.go.id/website/pdf_publikasi/ Statistik-Daerah-Kabupaten-Blitar-2015--.pdf.

BPS. (2017). Potential Center of Small and Medium Industries Production by Type, 2013. Retrieved on May 20, 2017 from Statistics Indonesia Website: https://blitarkab.bps.go.id/linkTabelStatis/view/ id $/ 317$.

Hebbar, K.B., Arivalagan, M., Manikantan, M.R., Mathew, A.C., Thamban, C., Thomas, G.V. and Chowdappa, P. (2015). Coconut inflorescence sap and its value addition as sugar - collection techniques, yield, properties and market perspective. Current Science, 109(8), 1-7. https:// doi.org/10.18520/cs/v109/i8/1411-1417

Ho, C.W., Wan Aida, W.M., Maskat, M.Y. and Osman, H. (2008). Effect of thermal processing of palm sap on physic-chemical composition of traditional palm sugar. Pakistan Journal of Biological Sciences, 11 (7), 989-995. https://doi.org/10.3923/ pjbs.2008.989.995

Hori, K., Surjoseputro, S., Purnomo, H., Foe, K. and Hashimura, F. (2000). Indigenous technology of coconut sugar production in the village of Genteng, 
Banyuwangi (East Java) and Dawam, Klungkung (Bali) and the knowledge about palm sugar by Japanese young people. Bulletin of Fukuoka University of Education, 50(5), 109-118.

Kalaiyarasi, K., Sangeetha, K. and Rajarajan, S. (2013). A comparative study on the microbial flora of the fresh sap from cut inflorescence and fermented sap (toddy) of Borrassus flabellifer Linn (Palmyrah tree) and of Cocos nucifera Linn (Coconut tree) to identify the microbial fermenters. International Journal of Research in Pure and Applied Microbiology, 3(3), 43-47.

Kapillan, R., Kailayalingam, R., Mahilrajan, S., and Srivijeindran, S. (2015). Determination of efficient fermentation inhibitor of sweet sap of Cocos nucifera and optimization of concentration for quality outputs in Northern Sri Lanka. International Journal of Scientific Research in Agricultural Sciences, 2(7), 166-174. http://dx.doi.org/10.12983/ ijsras-2015-p0166-0174

Kusumah, R.D. (1992). Study effect of adding food additive in aren (Arenga pinnata Merr) sap on the quality of brown sugar, palm sugar, sap syrup and white sugar (Mempelajari pengaruh penambahan pengawet pada nira aren (Arenga pinnata Merr) terhadap mutu gula merah, gula semut, sirup nira dan gula putih yang dihasilkan. Indonesia: Faculty of Agriculture Technology, Bogor Agriculture Institute, BSc. Thesis.

Martins, S.I.F.S., Jongen, W.M.F. and Van Boekel, M.A.J.S. (2001). A review of Maillard reaction in food and implications to kinetic modeling. Trends in Food Science and Technology, 11, 364-373. https:// doi.org/10.1016/S0924-2244(01)00022-X

Misra, B. (2016). Neera: The coconut sap: A review. International Journal of Food Science and Nutrition, 1(4), 35-38.

Nathanael, W.R.W. (1970). Coconut toddy tapping and cottage manufacture of treacle and jiggery. Ceylon Coconut Planters Review, 6, 63-65.

Phaichamnan, M., Posri, W. and Meenune, M. (2010). Quality profile of palm sugar concentrate produced in Songkhla province, Thailand. International Food Research Journal, 17, 425-432.

Purnomo, H. (1992). Sugar components of coconut sugar in Indonesia. ASEAN Food Journal, 7(4), 200-201.

Purnomo, H. (2007). Volatile components of coconut fresh sap, sap syrup and coconut sugar. ASEAN Food Journal, 14(1), 45-49.

Purnomo, H. and Mufida, L.H. (2004). Sugar components of fresh sap and sap syrup of coconut. ASEAN Food Journal, 13(3), 159-163.
Purnomo, H. and Surjoseputro, S. (2001). Traditional coconut sugar production in Indonesia: A comparative study on the technology and physicchemical properties of coconut sugar from four villages in East Java and Bali. The $11^{\text {th }}$ Biennial International Congress of Asian Regional Association for Home Economics (ARAHE), p. 1-6. Taiwan: Taipei.

SNI. (1992a). Indonesian National Standard for Sugar Analysis (SNI 01-2892-1992). National Standardization Agency of Indonesia.

SNI. (1992b). Indonesian National Standard for Microbe Contamination Test (SNI 01-2897-1992). National Standardization Agency of Indonesia.

Solanki, S. (2016). Palm Sugar is Progressing towards a strong growth by 2026. Retrieved on May 15, 2017 from Website: https://www.linkedin.com/pulse/palm -sugar-market-progressing-towards-strong-growth2026-solanki.

Srikaeo, K. and Thongta, R. (2015). Effects of sugar cane, palm sugar, coconut sugar and sorbitol on starch digestibility and physicochemical properties of wheat based foods. International Food Research Journal, 22(3), 923-929.

Ta'lin, T. (2013). Modification and Improvement of Inflorescence Cutter for Nira Tapping (Modifikasi dan perbaikan kinerja alat pengiris mayang kelapa untuk menyadap nira). Agritech, 33(4), 477-482.

Trinindad, T.P., Mallillin, A.C., Sagum, R.S. and Encabo, R.R. (2010). Glycemic index of commonly consumed carbohydrate foods in the Phillipines. Journal of Functional Foods, 2, 271-274. https:// doi.org/10.1016/j.jff.2010.10.002

Ysidor, K.N., Rachel, A.R., Jean-Louis, K.K., Muriel, O.D., Prades, K., Kouassi, K. and Marius, B.G.H. (2014). Glucide Factors of the Inflorescence Sap of Four Coconut (Cocos nucifera L.) Cultivars from Côte D'ivoire. International Journal of Biochemistry Research and Review, 4(2), 116-127. https:// doi.org/10.9734/IJBCRR/2014/7148 